\title{
10
}

\section{Design, Construction and Hydraulic Performance Assessment of an Infiltration Gallery}

\author{
Michael A. Gregory and David C. Arseneau
}

The Alton Mill is located in Caledon, Canada, on a tributary of the Credit River that discharges into Lake Ontario. The Alton Mill initiative is aimed at converting a century-old plus heritage stone mill and pond complex into an artisan oriented tourism destination.

A stormwater management servicing plan was developed to lessen the impact of this development on adjacent properties and on the receiving watercourse. The servicing plan featured a storm sewer and swale collection system along with an infiltration gallery designed to temporarily store surface runoff for subsequent percolation and groundwater recharge. Runoff is discharged evenly through a manifold perforated pipe system into the gallery, which is filled with continuous clear stone and covered with native soil material. Runoff exceeding the capacity of the collection system or gallery is designed to discharge via overland sheet flow into the receiving watercourse.

Construction of the stormwater facilities was completed in September 2008. While no formal post-construction monitoring was required as part of the permitting process, additional analysis was undertaken in January 2010. Continuous hydrologic simulation was used to evaluate the long term water balance and to verify the system's hydraulic performance under a full range of storm events, using a wider array of risk based indicators including the depth and velocity of infiltration gallery overflows during extreme rainfall events.

Gregory, M. and D. Arseneau. 2012. "Design, Construction and Hydraulic Performance Assessment of an Infiltration Gallery." Journal of Water Management Modeling R245-10. doi: 10.14796/JWMM.R245-10. (C) CHI 2012 www.chijournal.org ISSN: 2292-6062 (Formerly in On Modeling Urban Water Systems. ISBN: 978-0-9808853-7-8) 


\subsection{Background}

The Alton Mill is located in Caledon, Ontario, situated alongside a cold water fishery (Shaws Creek, a tributary of the Credit River), which ultimately discharges into Lake Ontario. The Alton Mill initiative is shown in Figure 10.1. The site is located in an industrial land use zone and has a total area of 1.07 ha (2.64 acre). It is a multi-faceted public-private partnership aimed at converting a century-old plus heritage stone mill and pond complex into an artisan oriented tourism destination.

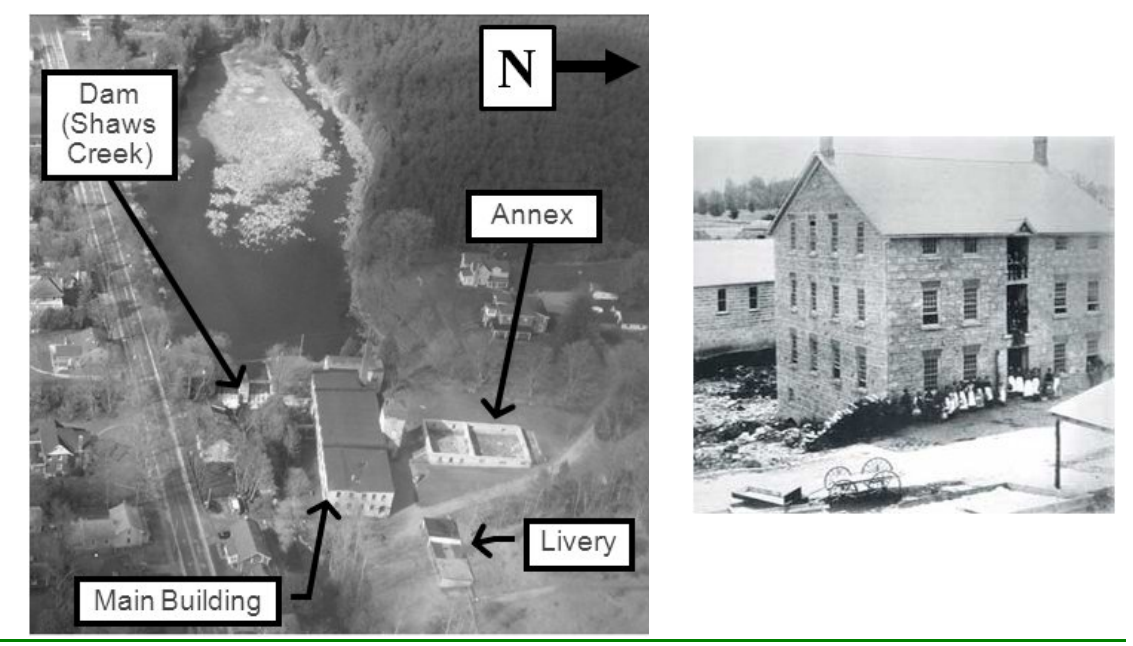

Figure 10.1 Alton Mill initiative (original building on the right).

In 2006, The Alton Development Inc. submitted rezoning and site plan applications for this initiative, proposing future building additions, parking areas, and driveway alterations to service adjacent property owners. In keeping with the Town of Caledon and Credit Valley Conservation (CVC) requirements, a stormwater management servicing plan was proposed to lessen the impact of this development on both the adjacent properties and receiving watercourse (Shaws Creek), featuring both water quantity and quality controls. The servicing plan was completed as part of the submittal for site plan approval and permitting in October 2006.

\subsection{Design}

Figure 10.2 shows the proposed stormwater management system layout in the southern portion of the property. The receiving watercourse, Shaws Creek, runs 
to the east (left to right) just below the bottom of Figure 10.2. The stormwater management servicing plan for the Alton Mill initiative was designed to reduce development impacts on adjacent properties and the receiving watercourse. This initiative included additional impervious areas and significant regrading of the site. Proposed stormwater management facilities were sized to accommodate runoff for ultimate build-out conditions.

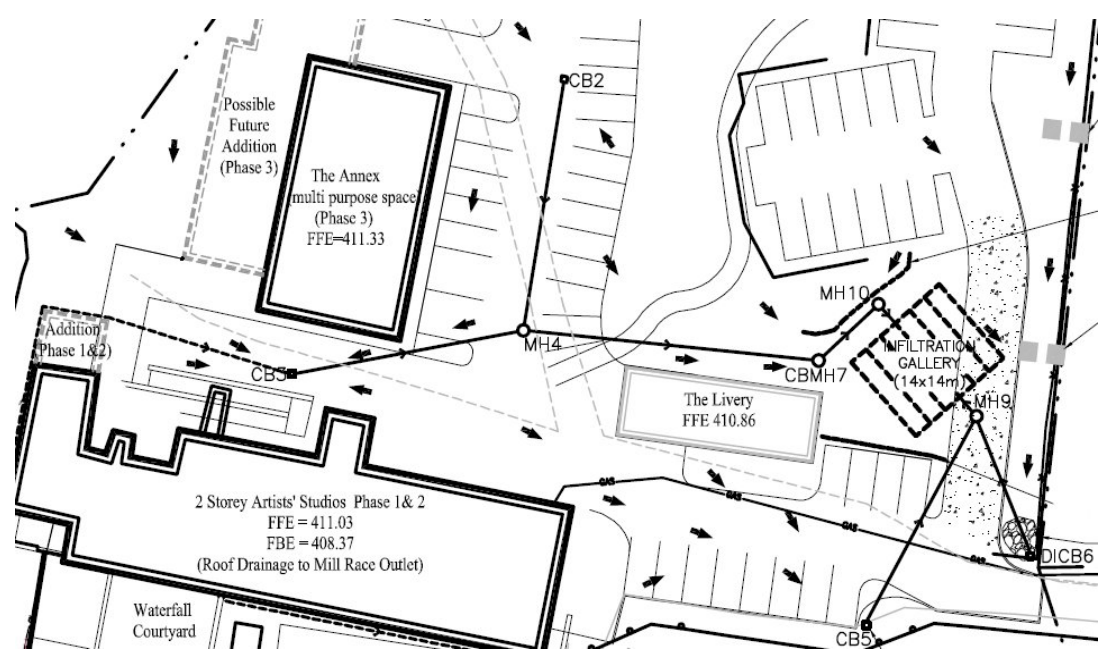

Figure 10.2 Proposed stormwater management system layout.

Among the design objectives was preserving the natural infiltration features of the underlying soils on site and discharge runoff from frequent rainfall events into a central infiltration gallery. Soils in this region are very welldrained and support the design function of encouraging groundwater replenishment rather than direct disposal of runoff to the adjacent watercourse. A system of catchbasin inlets and storm sewer pipes was designed to direct surface water runoff into the infiltration gallery. The gallery was designed to temporarily store surface runoff for subsequent percolation and groundwater recharge. Flows exceeding the capacity of the collection system or infiltration gallery will be discharged by overland flow into Shaws Creek.

Roof runoff from a portion of the main building is collected by a roof drain that is discharged to the mill race within the building. The mill race discharges to a culvert outlet in Shaws Creek at the eastern end of the building. Before development, stormwater runoff from the remainder of the site discharged by overland sheet flow to the southeast directly into Shaws Creek.

In addition to the main building, major existing structures include the Livery and Annex buildings. A gravel laneway traverses the site and there is a gravel 
parking area between the Livery and main building. The remainder of the site was generally grassed, with large trees in the center.

A recent version of the stormwater management model (SWMM) was used to represent the hydrology and hydraulics of the site and stormwater facilities (USEPA, 2010).

Development of the stormwater servicing plan followed a traditional design approach to achieve water quantity control objectives using event based hydrology. That is, facilities were designed such that post-development peak flows, flood stages, and velocities did not exceed pre-development conditions for a range of prescribed design storm events.

A system of swales, catchbasin inlets, and storm sewer pipes was designed to direct surface water runoff into the infiltration gallery. The configuration and sizes of pipes, manholes, and catchbasins (as shown in Figure 10.2) were determined according to the municipal design standards (Town of Caledon, 2006). Storm sewer pipes represented in the model ranged in size from $250 \mathrm{~mm}$ (10 in.) to $300 \mathrm{~mm}$ (12 in.) diameter with a total length of $122 \mathrm{~m}$ (400 ft).

Past soil investigation studies by others in July 1998 and June 2006 were based on boreholes and test pits drilled on the site and confirmed that native subsoils (i.e. underlying the top $300 \mathrm{~mm}$ [12 in.] of topsoil) are composed largely of sand and gravel, with traces of silt and are suitable for infiltration facilities. The texture of this subsoil encourages the movement of water even when thoroughly wetted and as a result the soil has a relatively high infiltration rate. The location of the proposed infiltration gallery coincided with a test pit location in the June 2006 investigation.

Profile views of the infiltration gallery design are shown in Figure 10.3.

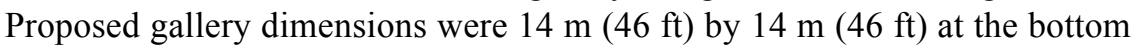
(i.e. $407.3 \mathrm{~m}$ elevation) with $1: 1$ sideslopes to a top gallery elevation of $408.8 \mathrm{~m}$. Runoff is directed into the gallery via $300 \mathrm{~mm}$ (12 in.) header pipes at each end and distributed evenly through a manifold of seven $150 \mathrm{~mm}$ (6 in.) perforated pipes. The gallery was filled with a continuous layer of $50 \mathrm{~mm}$ ( 2 in.) clear stone, wrapped in filter cloth, and covered with native soil material. A void ratio of $30 \%$ was used to determine the available gallery storage volume. Catchbasin and manhole storage (including the manholes at either end of the gallery) was represented in the hydraulic model.

Surface storage was represented in the model in order to track surface flooding depths for the larger rainfall events. Further, surface overflow channels were represented in the model to account for overflows when the conveyance capacity of the storm sewer pipes was exceeded and the computed hydraulic gradeline exceeded the ground elevation at any location within the collection system. These overflows were designed to be discharged via overland sheet 
flow into Shaws Creek within acceptable tolerances of depth and velocity specified by the local permitting agencies.
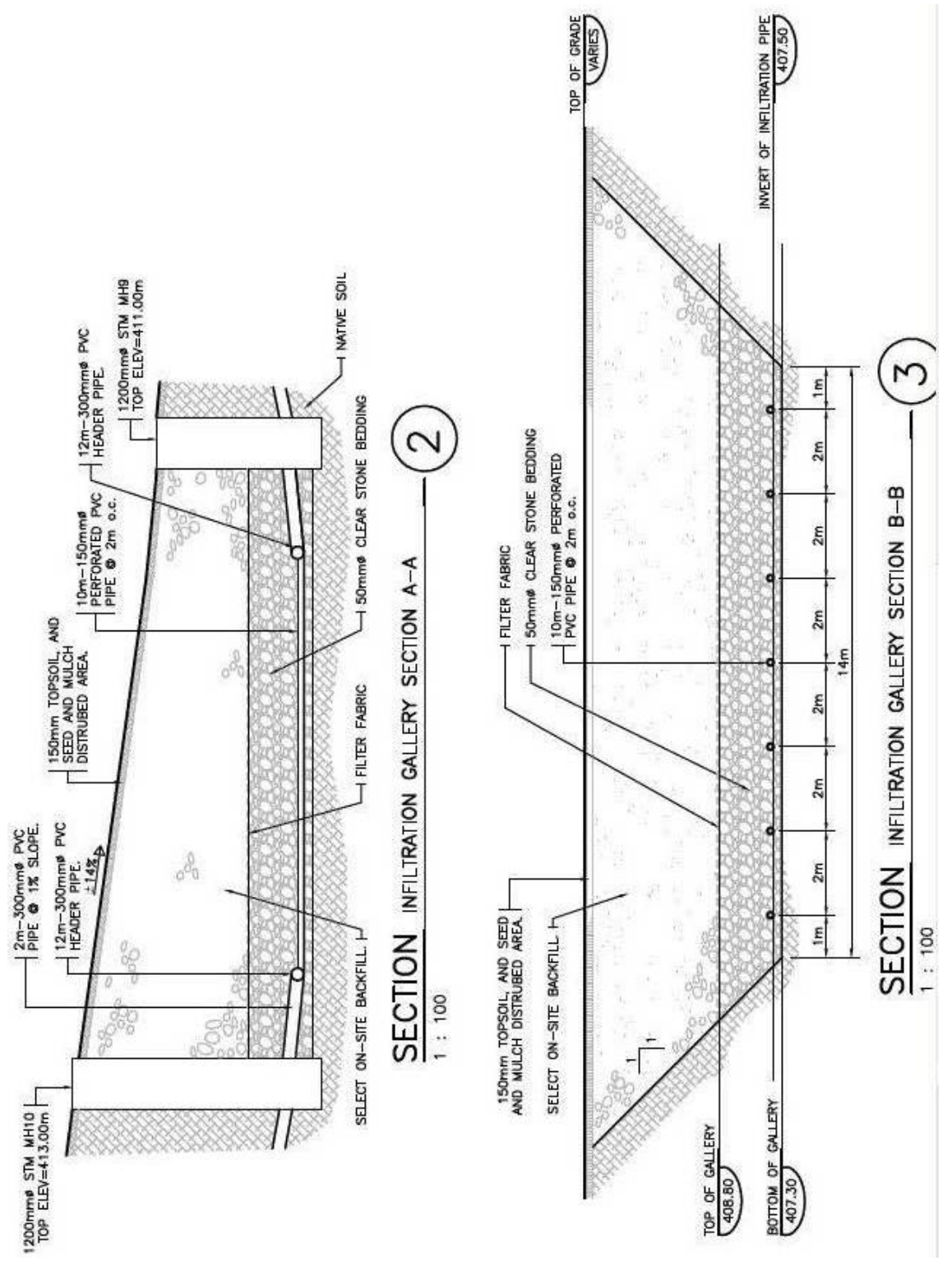

Figure 10.3 Profile views of infiltration gallery. 
During construction of the gallery in June 2008, bedrock was discovered at an approximate elevation of $407.0 \mathrm{~m}$ (note: the bottom of the gallery was initially proposed to be $406.5 \mathrm{~m}$ ). Coincidently, five test pits were dug in the vicinity of the proposed gallery location during the 2006 soil investigation, and none revealed the presence of bedrock. Due to the bedrock, the size and elevation of the gallery was redesigned with the final orientation as shown in Figure 10.2.

Based on the 2006 soil investigation, a saturated hydraulic conductivity of $0.00021 \mathrm{~m} / \mathrm{s}(30 \mathrm{in} . / \mathrm{hr})$ was determined. The design of the gallery took advantage of this high infiltration capacity, and therefore a peak infiltration rate of $0.025 \mathrm{~m}^{3} / \mathrm{s}\left(0.9 \mathrm{ft}^{3} / \mathrm{s}\right)$ was used to reflect infiltration through the sides of the gallery into the native soils. Infiltration through the bottom of the gallery was assumed to be zero due to the underlying bedrock. The following rating curve was used in the model to represent the rate of infiltration discharged from the gallery (with linear interpolation assumed between values):

no infiltration when the gallery is dry (i.e. hydraulic gradeline is at or below the gallery bottom elevation of $407.3 \mathrm{~m}$ ); two-thirds of the peak infiltration capacity, $0.017 \mathrm{~m}^{3} / \mathrm{s}\left(0.6 \mathrm{ft}^{3} / \mathrm{s}\right)$ when the hydraulic gradeline reaches an elevation of $407.8 \mathrm{~m}$; and

- peak infiltration capacity of $0.025 \mathrm{~m}^{3} / \mathrm{s}\left(0.9 \mathrm{ft}^{3} / \mathrm{s}\right)$ when the hydraulic gradeline exceeds the gallery top elevation of $408.8 \mathrm{~m}$.

Modeling results for proposed site conditions indicated that stormwater runoff for all design storms up to and including the $25 \mathrm{y}$ return period event will be contained onsite and dispersed through the proposed infiltration gallery without surface discharge to the receiving watercourse. Further, the peak hydraulic gradeline remained below the top of the infiltration gallery (i.e. elevation $408.8 \mathrm{~m}$ ) for all design storms up to and including the $10 \mathrm{y}$ return period event.

A detailed analysis of the structural impact of increased groundwater levels on basement floor slabs in adjacent buildings was not conducted. Peak stage results were compared to the critical threshold elevation of the main building floor slab $(408.37 \mathrm{~m})$, located approximately $30 \mathrm{~m}(100 \mathrm{ft})$ from the infiltration gallery. It was also confirmed that the peak hydraulic gradeline remained below basement floor slab elevations in all adjacent buildings for all design storms up to the 5 y return period event. Nevertheless, it was decided to install floor drains in the main building basement as a precaution.

\subsection{Construction}

Construction of the stormwater facilities began in May 2008 and was completed in September 2008. Figure 10.4 includes photos taken during construction of 
the infiltration gallery in June and July 2008. The upper left photo shows the assembly of the header manifold and perforated distribution pipes. The upper right photo shows the installation of the porous media on top of the distribution pipes. The bottom left photo shows the placement of the filter cloth on top of the infiltration gallery. The bottom right photo shows the placement of native soil material over the filter cloth.

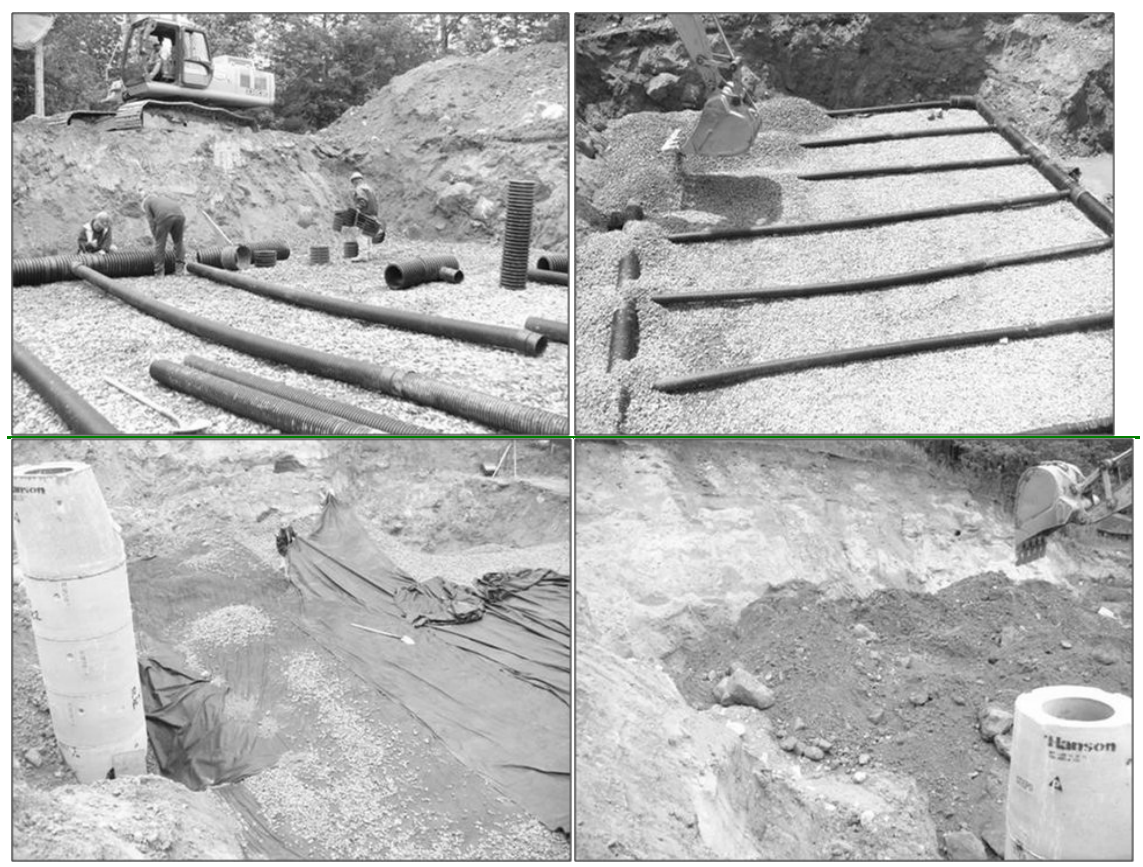

Figure 10.4 Infiltration gallery construction photos.

The servicing plan included temporary erosion and sedimentation controls during the construction period to protect the porous media in the infiltration gallery as well as limit the impact on adjacent downstream properties and the receiving watercourse. Given the high cost of replacing the porous media in the gallery, it was critical to incorporate permanent sediment and silt controls. Structures CB2, CB3, CB5, DICB6, and CBMH7 were equipped with $600 \mathrm{~mm}$ (24 in.) sumps for sediment capture. Further, hooded outlet covers were installed in these structures to restrict sediment and silt from entering the pipes.

Although these controls were designed to limit the entry of fine sediment into the infiltration gallery, this facility essentially acts as a filter and will eventually become clogged. A scenario was simulated that represented a failure of the infiltration gallery under frozen or clogged media conditions, in which 
there was no infiltration. Further, the available storage within the gallery was greatly reduced in this failure scenario (i.e. $5 \%$ void ratio in the porous media). Model results confirmed the resulting overflow depths and velocities were within acceptable limits for the $100 \mathrm{y}$ design storm event.

\subsection{Hydraulic Performance Evaluation}

With larger stormwater facilities, permitting agencies typically require a formal post-construction monitoring program to confirm the facility achieves its design objectives. Such a monitoring program was not required as part of the permitting process for this project, given the relatively small size and limited impact of future land use activities. No stormwater overflows from the collection system have been observed since the gallery was constructed over two years ago. In spite of this, a long term performance evaluation was conducted following construction as a matter of due diligence

As noted earlier, stormwater facilities were designed using a traditional event based hydrology approach, which is most appropriate for flood control where the design objective is to collect and dispose of runoff in a manner that protects public safety and minimizes property damage during extreme events. Water conservation was an additional goal for the Alton Mill initiative, where the design objective is to capture and retain runoff in a manner that preserves the natural hydrologic balance onsite. Water balance controls are implicit in low impact development (LID) design, intended to manage runoff volumes in an attempt to maintain predevelopment hydrologic conditions.

Continuous hydrologic simulation requires long term meteorological input that encompasses a range of historical rainfall events as well as the dry weather periods in between, not just selected design storms that characterize extreme events. Continuous simulation is therefore most appropriate for LID facilities, such as the Alton Mill infiltration gallery. Other design objectives such as maintaining baseflows in receiving watercourses, maintaining appropriate water level fluctuations in wetlands, groundwater recharge and discharge, water supply and wellhead protection, and natural habitat impacts also require a long term water balance approach using long term (i.e. multiple year) continuous simulation.

\subsubsection{Additional rainfall analysis}

The original design was based on design storm events prescribed in the local design standards. These events were based on rainfall statistics from a weather station in downtown Toronto, approximately $60 \mathrm{~km}(37 \mathrm{mi})$ southeast of the study area. 
After construction of the Alton Mill infiltration gallery, additional rainfall data were collected from the Elora research station, which is operated by the University of Guelph and is located $37 \mathrm{~km}$ (23 mi) southwest of the study area. As well as being about $40 \%$ closer, the Elora rain gauge is situated in a rural setting similar to that of the Alton Mill and along the same prevailing storm track (the typical storm cell direction is to the northeast). It was felt that rainfall data from the Elora gauge would be more representative of conditions at the Alton Mill site than that implicit in the prescribed Toronto design storm events.

A total of $19 \mathrm{y}$ tipping bucket data was acquired from the Elora station, representing the period of record from 1989 through 2007. This rain gauge is not operated during the winter months and therefore only data from April through October was used as input for continuous simulation.

Intensity-duration-frequency statistics were also analyzed for this same rainfall period of record using the NetSTORM program (Heineman, 2004). Statistics were determined for various return periods over durations ranging from $5 \mathrm{~min}$ to $24 \mathrm{~h}$. The rainfall quantities were then fitted to a $24 \mathrm{~h}$ distribution and centered about time 12:00 (i.e. the peak $5 \mathrm{~min}$ intensity fell between 12:00 and 12:05, the peak 10- min intensity fell between 11:55 and 12:05, etc.).

The resulting design storm event rainfall totals used in the post-construction performance assessment were:

2 y return period/24 h duration: $44.6 \mathrm{~mm}$ (1.8 in.);

$5 \mathrm{y} / 24 \mathrm{~h}: 61.2 \mathrm{~mm}(2.4 \mathrm{in}$.$) ;$

$10 \mathrm{y} / 24 \mathrm{~h}: 74.2 \mathrm{~mm}$ (2.9 in.); and

$25 \mathrm{y} / 24 \mathrm{~h}: 92.9 \mathrm{~mm}$ (3.7 in.).

Table 10.1 compares the peak intensities and total rainfall depth for the various design storm events and selected durations.

Table 10.1 Comparison of design storm events

\begin{tabular}{|c|c|c|c|c|}
\hline \multirow{2}{*}{$\begin{array}{l}\text { Storm } \\
\text { Event }\end{array}$} & \multicolumn{3}{|c|}{ Peak Intensity $(\mathrm{mm} / \mathrm{hr})$} & \multirow{2}{*}{$\begin{array}{c}\text { Depth }(\mathrm{mm}) \\
\text { 4-hr }\end{array}$} \\
\hline & 10-min & $30-\min$ & 1-hr & \\
\hline \multicolumn{5}{|l|}{ Original Design } \\
\hline 2-year/4-hour & 82 & 41 & 25 & 34.8 \\
\hline 5-year/4-hour & 113 & 56 & 34 & 46.3 \\
\hline 10-year/4-hour & 136 & 65 & 39 & 54.1 \\
\hline 25-year/4-hour & 160 & 74 & 45 & 62.2 \\
\hline \multicolumn{5}{|c|}{ Post-Construction Analysis } \\
\hline 2-year/24-hour & 133 & 60 & 35 & 44.6 \\
\hline 5-year/24-hour & 180 & 75 & 44 & 61.2 \\
\hline 10-year/24-hour & 216 & 88 & 53 & 74.2 \\
\hline 25-year/24-hour & 273 & 110 & 67 & 92.9 \\
\hline \multicolumn{5}{|l|}{ Difference } \\
\hline 2-year & $62 \%$ & $48 \%$ & $39 \%$ & $28 \%$ \\
\hline 5-year & $59 \%$ & $35 \%$ & $31 \%$ & $32 \%$ \\
\hline 10-year & $60 \%$ & $36 \%$ & $35 \%$ & $37 \%$ \\
\hline 25-year & $71 \%$ & $47 \%$ & $50 \%$ & $49 \%$ \\
\hline
\end{tabular}


The events used in the original design model are shown at the top of the table and those based on the Elora rain gauge are shown in the middle. The difference between the post-construction analysis events and the original design values are shown at the bottom of the table. The values for the Elora rain gauge are consistently much higher than the original design storms for the range of peak rainfall intensities shown and total rainfall depth over a $4 \mathrm{~h}$ period.

The period of record used to define the original design storm events is not known, however it is likely in the range of $50 \mathrm{y}$ to $75 \mathrm{y}$. An evaluation of the statistical significance of the shorter 19 y period of record at the Elora station, in relation to adjacent long term rain gauges, has not been conducted.

Table 10.2 shows the April through October rainfall totals taken from the most recent published values for Climate Normals at the nearest long term weather stations (Environment Canada, 2008). Stations are distinguished according to location and are listed in increasing order of distance from the Alton Mill study area. The table shows the average annual rainfall and the difference compared to the Elora average value (533.1 mm for the period 1989-2007).

Table 10.2 suggested that the Elora rainfall totals were significantly higher than the Toronto rainfall totals. The table also confirms that the Elora average is higher than those at weather stations along the Lake Ontario waterfront (southeast of the study area). However, Table 10.2 suggests that the Elora rainfall dataset is well within the range of long term normal values for weather stations located along the prevailing storm track (to the southwest of the study area).

Table 10.2 Comparison of average annual rainfall (Apr 1-Oct 31).

\begin{tabular}{|c|c|c|}
\hline $\begin{array}{l}\text { Weather } \\
\text { Station }\end{array}$ & $\begin{array}{c}\text { Average Rainfall }(\mathrm{mm}) \\
\text { (Apr } 1 \text { - Oct 31) }\end{array}$ & $\begin{array}{l}\text { Difference vs. } \\
\text { Elora Station }\end{array}$ \\
\hline \multicolumn{3}{|l|}{ Stations Adjacent to Lake Ontario } \\
\hline Toronto Airport & 503.9 & $-5 \%$ \\
\hline Oakville Southeast WPCP & 505.2 & $-5 \%$ \\
\hline Hamilton Royal Botanical Gardens & 538.8 & $1 \%$ \\
\hline \multicolumn{3}{|c|}{ Stations Along Prevailing Storm Track } \\
\hline Fergus Shand Dam & 581.3 & $9 \%$ \\
\hline Guelph Arboretum & 571.4 & $7 \%$ \\
\hline Waterloo Wellington Airport & 556.7 & $4 \%$ \\
\hline Cambridge Galt Treatment Plant & 572.0 & $7 \%$ \\
\hline Stratford Treatment Plant & 592.5 & $11 \%$ \\
\hline
\end{tabular}

While the Elora rainfall data is more appropriate from a geographical and hydrologic perspective than the Toronto data, it is not clear how the shorter period of record reduces this advantage. Until further statistical analysis of rainfall intensity and depth characteristics is conclusive, the comparison of model results and performance evaluation presented below should be considered for illustrative purposes only. 


\subsubsection{Model adjustments for continuous simulation}

Evaporation during intense, short duration design storm events is negligible and was not considered in the hydrologic model used as the basis for design. For continuous simulation however, evaporation is a significant hydrologic variable.

Evaporation data were input as a daily abstraction rate for each calendar month, including the following values during the simulation period:

April, $1.1 \mathrm{~mm} /$ day

- May, $2.0 \mathrm{~mm} /$ day

- June, $4.9 \mathrm{~mm} /$ day

- July, $5.2 \mathrm{~mm} /$ day

- August, $4.9 \mathrm{~mm} / \mathrm{day}$

- September, $3.3 \mathrm{~mm} /$ day

- October, $2.3 \mathrm{~mm} /$ day

These values represent a total potential evaporation of $725 \mathrm{~mm}$ over the period April through October. The total potential evaporation for all months matches the Toronto annual lake evaporation rate of $813 \mathrm{~mm}$.

Seasonal fluctuations in groundwater levels can also affect the performance of stormwater management systems. The capacity of infiltration facilities in particular will be greatly reduced when groundwater levels rise above the bottom of the facility. The June 2006 soils investigation was conducted during the anticipated high groundwater period and there was no evidence of seasonal fluctuations that would impact the performance of the gallery. Consequently, groundwater impacts were not considered in the analysis.

As noted earlier, precipitation during winter months was not included in the rainfall record. Consequently, snowmelt was not considered in the analysis. Model boundary conditions must also be considered when adapting design storm event models for use with continuous simulation. Here, the tailwater conditions represented in Shaws Creek did not change compared to the original design model. The only hydraulic connection to the receiving watercourse is via surface overflow. Therefore, flow conditions in Shaws Creek, including seasonal variations in channel roughness, do not impact the performance of the infiltration gallery.

\subsubsection{Model results using new rainfall data}

The performance evaluation included a variety of hydraulic indicators to compare against pre-development conditions, including:

rate of surface runoff;

volumetric proportions of various hydrologic components (evapotranspiration, infiltration, and surface runoff); 
- $\quad$ peak stage in relation to various threshold elevations (ground surface and basement floor slab in adjacent buildings);

- peak routed flow rates, particularly surface overflows to the receiving watercourse (Shaws Creek) and groundwater infiltration discharged from the gallery;

- peak routed runoff volumes, particularly surface overflows and infiltration from the gallery;

- flow frequency curves quantifying discharge into the receiving watercourse; and

- $\quad$ peak depth and velocity of surface overflows in relation to a variety of flood damage/risk envelopes.

It is beyond the scope of this chapter to present results for all of the performance indicators listed above. Results that highlight differences between eventbased and continuous simulation are described.

\section{Water Balance}

Table 10.3 summarizes the water balance and runoff volume results under existing and proposed conditions. The results are shown for the design storm events derived from the Elora 1989-2007 rainfall dataset, as well as the continuous simulation results using the same Elora data.

\section{Table 10.3 Water balance results}

\begin{tabular}{|c|c|c|c|c|c|c|c|c|}
\hline \multirow[b]{2}{*}{ Storm Event } & \multicolumn{2}{|c|}{ Evaporation } & \multicolumn{2}{|c|}{ Infiltration } & \multicolumn{4}{|c|}{ Surface Runoff } \\
\hline & $(\mathrm{mm})$ & $\%$ & $(\mathrm{~mm})$ & $\%$ & $(\mathrm{~mm})$ & $\%$ & Coeff. & \begin{tabular}{|c} 
Volume \\
$\left(\mathrm{m}^{3}\right)$
\end{tabular} \\
\hline \multicolumn{9}{|c|}{ Existing Conditions } \\
\hline 2-year/24-hour & 0.0 & $0.0 \%$ & 42.9 & $76.7 \%$ & 13.0 & $23.3 \%$ & 0.23 & 137 \\
\hline 5-year/24-hour & 0.0 & $0.0 \%$ & 52.2 & $71.1 \%$ & 21.2 & $28.9 \%$ & 0.29 & 225 \\
\hline 10-year/24-hour & 0.0 & $0.0 \%$ & 59.1 & $67.3 \%$ & 28.7 & $32.7 \%$ & 0.33 & 305 \\
\hline 25-year/24-hour & 0.0 & $0.0 \%$ & 67.2 & $60.7 \%$ & 43.4 & $39.3 \%$ & 0.39 & 461 \\
\hline $1989-2007$ & 411.0 & $4.3 \%$ & 8720.1 & $90.9 \%$ & 458.4 & $4.8 \%$ & 0.05 & 4,887 \\
\hline \multicolumn{9}{|c|}{ Proposed Conditions } \\
\hline 2-year/24-hour & 0.0 & $0.0 \%$ & 26.1 & $46.6 \%$ & 29.9 & $53.4 \%$ & 0.52 & 307 \\
\hline 5-year/24-hour & 0.0 & $0.0 \%$ & 32.2 & $43.8 \%$ & 41.4 & $56.2 \%$ & 0.55 & 429 \\
\hline 10-year/24-hour & 0.0 & $0.0 \%$ & 36.6 & $41.6 \%$ & 51.4 & $58.4 \%$ & 0.57 & 537 \\
\hline 25-year/24-hour & 0.0 & $0.0 \%$ & 41.3 & $37.3 \%$ & 69.5 & $62.7 \%$ & 0.62 & 730 \\
\hline $1989-2007$ & 1645.4 & $17.1 \%$ & 5522.6 & $57.5 \%$ & 2443.6 & $25.4 \%$ & 0.26 & 26,098 \\
\hline
\end{tabular}

The unit-area depth and proportion of the hydrologic components are listed in Table 10.3 for each storm event. As noted earlier, evaporation was not simulated for the design storm events, but was represented in the continuous simulation runs. The middle set of columns shows the volume of rainfall that was infiltrated into the soil. It does not include any runoff collected by the stormwater management system and discharged through the infiltration gallery. Routed runoff rates and volumes are tabulated later in this section. 
The final set of columns in Table 10.3 shows the surface runoff quantities. The proportion of surface runoff is more popularly known as the volumetric runoff coefficient and expressed as a fraction of the total rainfall (Coeff. column). In addition to the unit-area depth of runoff, the total volume of surface runoff is shown in the final column.

As expected, the increased imperviousness from redevelopment activities results in a decrease in the amount of surface infiltration and corresponding increase in the surface runoff volume for all storm events.

\section{Surface Runoff Volume}

The total surface runoff volume (i.e., the portion that is hydraulically routed through the stormwater management system) results are summarized in Table 10.4. This table confirms the primary benefit of stormwater infiltration facilities; namely, exceptional performance in reducing surface runoff volumes. In this case, the routed surface overflow volume is kept below pre-development levels for all storms events. The $53 \%$ reduction in runoff volume for the continuous simulation run represents an average runoff volume reduction of $3 \% / y$.

Table 10.4 Total surface runoff volume results.

\begin{tabular}{|c|c|c|c|c|c|}
\hline \multirow[b]{2}{*}{ Location/Description } & \multicolumn{5}{|c|}{ Total Runoff Volume $\left(\mathrm{m}^{3}\right)$} \\
\hline & $\begin{array}{l}2-\mathrm{yr} / \\
24-\mathrm{hr} \\
\text { Event }\end{array}$ & $\begin{array}{c}5-y r / \\
24-h r \\
\text { Event }\end{array}$ & $\begin{array}{l}10-y r / \\
24-h r \\
\text { Event }\end{array}$ & $\begin{array}{l}25-\mathrm{yr} / \\
24-\mathrm{hr} \\
\text { Event }\end{array}$ & $\begin{array}{l}1989- \\
2007\end{array}$ \\
\hline \multicolumn{6}{|l|}{ Existing Conditions } \\
\hline Surface overflow volume to Shaws Creek & 137 & 225 & 305 & 461 & 4,887 \\
\hline \multicolumn{6}{|l|}{ Proposed Conditions } \\
\hline Infiltrated volume from gallery & 257 & 292 & 319 & 356 & 23,992 \\
\hline Surface overflow volume to Shaws Creek & 53 & 140 & 221 & 377 & 2,310 \\
\hline Difference compared to Existir & $-61 \%$ & $-38 \%$ & $-28 \%$ & $-18 \%$ & $-53 \%$ \\
\hline
\end{tabular}

The bottom rows of Table 10.4 compare the proportion of surface runoff that is discharged into the groundwater system (via the infiltration gallery) versus the runoff disposed into the receiving watercourse. The chart in Figure 10.5 shows results for the 5 y return period event, where approximately one third of the surface runoff volume was discharged into the receiving watercourse and two thirds to groundwater via the infiltration gallery. The chart in Figure 10.6 shows continuous simulation results and indicates a much improved performance in terms of onsite volume control, with over $90 \%$ of the surface water discharged through the infiltration gallery.

One advantage of continuous simulation is that it better expresses the proportion of hydrologic components, as illustrated in the water balance results presented above. Water balance proportions for design storm events are necessarily biased toward rare events. Further, such events embody the statistical 
characteristics of rainfall and therefore any resulting water balance calculations inherently assume the same statistical characterization, which is not realistic (Adams and Howard, 1986). With the appropriate meteorological input, water balance results for continuous simulation approach the long term average proportions, since they encompass the full range of rainfall events, both common and rare.

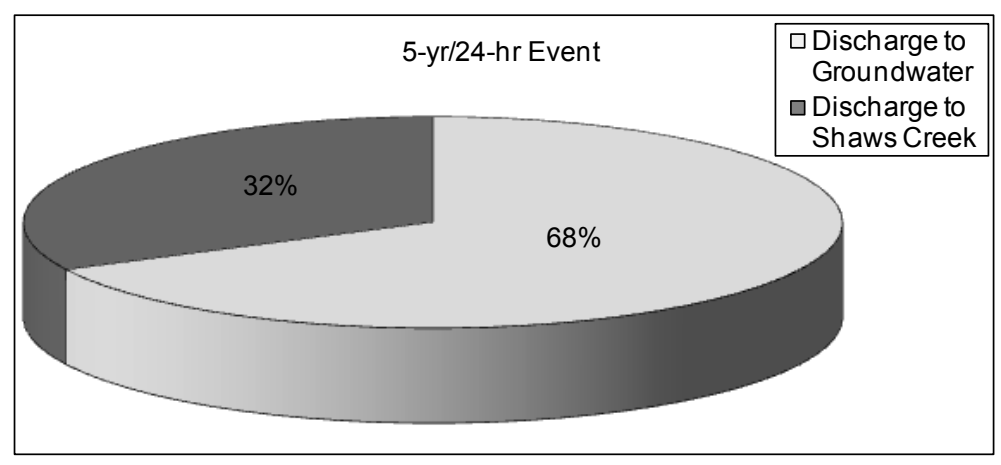

Figure 10.5 Distribution of surface runoff (design storm event).

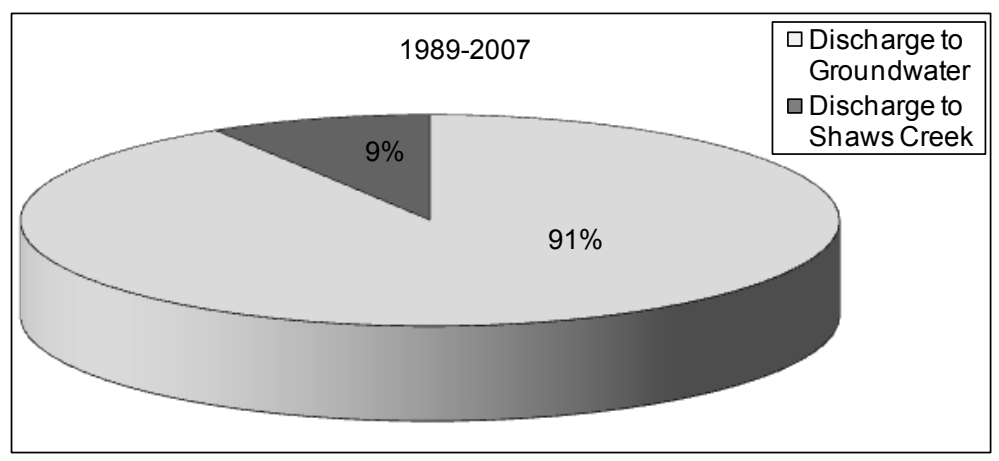

Figure 10.6 Distribution of surface runoff (continuous simulation).

\section{Peak Flood Stage}

Peak flood stage results indicate a very different level of performance when compared to results using the original design storm events. The peak stage results for the infiltration gallery (model junction MH9) in the original design model were described in Section 10.2. Peak stage results for the gallery using the new design storm events based on Elora rainfall data are:

$2 \mathrm{y} / 24 \mathrm{~h}$ event: $409.53 \mathrm{~m}$ (1.44 m [ $4.7 \mathrm{ft}]$ higher than the original design model);

$5 \mathrm{y} / 24 \mathrm{~h}$ event: $409.58 \mathrm{~m}$ (1.14 m [3.7 ft] higher); 
. $10 \mathrm{y} / 24 \mathrm{~h}$ event: $409.62 \mathrm{~m}$ (0.84 m [2.8 ft] higher); and

$25 \mathrm{y} / 24$ h event: $409.68 \mathrm{~m}$ (0.24 m [0.8 ft] higher).

It is common to assess the hydraulic performance of a stormwater management system or facility through a level of service analysis that compares peak stage results to critical threshold elevations (Gregory et. al., 2003). As noted earlier, the basement floor slab elevation of the main building $(408.37 \mathrm{~m})$ is one such threshold that was monitored during the design phase. Results for the original design storm events suggested this threshold would be exceeded for events greater than the 5 y return period event. However, results using the new rainfall data indicated this threshold is greatly exceeded even for the 2 y event. In this case, the structural impact of increased groundwater levels on the basement floor slab presents a valid concern. Fortunately this concern was addressed during construction, when it was decided to install floor drains in the main building basement as a precaution.

The other critical thresholds in this assessment included the overflow spill elevations. Peak stages that exceed the rim elevations at catchbasins and inlets represent surface overflows from the collection system. As noted in Section 10.2 , there were no surface overflows indicated for the original design storm events, including the $25 \mathrm{y}$ return period event. However, numerous surface overflows were indicated for all of the storm events using the new rainfall data.

The performance assessment based on peak computed stages illustrates the high sensitivity and dependence on rainfall input. Using the prescribed rainfall in the municipal design standards leads to the conclusion that a high level of service is provided by the stormwater management system. Using rainfall input derived from an analysis of more recent and more hydrologically appropriate measurements leads to the conclusion that a very low level of service is provided.

\section{Flow Frequencies}

Continuous simulation allows a statistical analysis to be conducted on the resulting computed runoff characteristics (e.g., volume, flow depth, velocity, or discharge rate). This is very different from event-based simulation, where the long term measured rainfall has been replaced by a statistical representation of specific events and it is assumed that the resulting computed runoff is characterized by the same statistics.

A common statistical analysis of continuous simulation results involves the development of frequency curves of selected computed runoff characteristics. Figure 10.7 presents the flow frequency curve under proposed conditions, showing the rate of discharge into Shaws Creek on the vertical axis and the return period in years on the horizontal axis. 


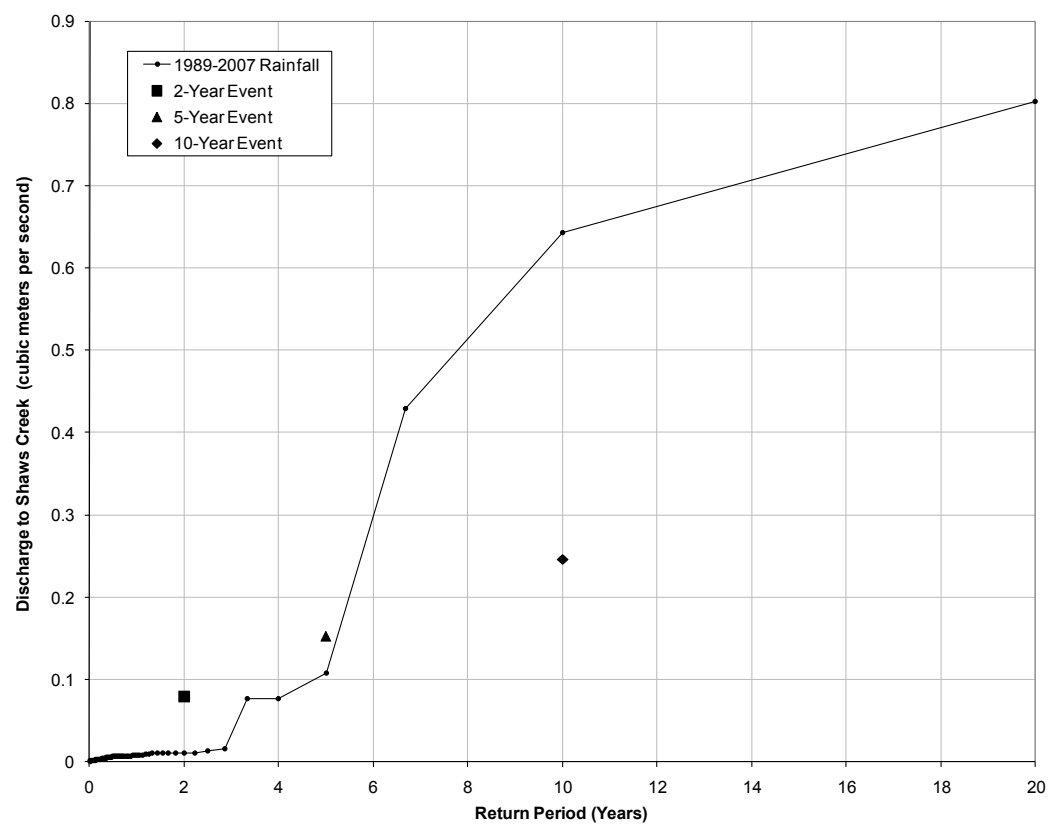

Figure 10.7 Flow rate comparison (continuous simulation versus design storm events).

The majority of runoff producing events (over 2220 in total) feature flow rates below $0.02 \mathrm{~m}^{3} / \mathrm{s}\left(0.7 \mathrm{ft}^{3} / \mathrm{s}\right)$, representing runoff from the small subcatchments that directly discharge into Shaws Creek. For the 19 y period of record, there are only six events that exceeded a flow rate of $0.02 \mathrm{~m}^{3} / \mathrm{s}\left(0.7 \mathrm{ft}^{3} / \mathrm{s}\right)$, representing surface overflows when the capacity of the collection system or infiltration gallery was exceeded. This uneven distribution of events explains the smooth frequency curve below a 3 y return period and the less elegant curve at higher return periods in Figure 10.7.

Figure 10.7 includes results from the design storm hyetographs that were developed from the same $19 \mathrm{y}$ rainfall record used for continuous simulation. In the original design model, runoff from the 25 y return period event was contained on site. However, with the new design event hyetographs, discharge into the receiving watercourse was noted for the 2 y event $\left(0.08 \mathrm{~m}^{3} / \mathrm{s}\left[2.8 \mathrm{ft}^{3} / \mathrm{s}\right]\right.$ as plotted in Figure 10.7).

Comparing the event based and continuous simulation results in Figure 10.7 suggests a wide discrepancy in inferences about the performance of the infiltration gallery. While the $5 \mathrm{y}$ return period event closely matches continuous simulation results, the 2 y return period event significantly overpredicts flows and the $10 \mathrm{y}$ event significantly underpredicts flows. 


\section{Peak Flood Depth and Velocity}

Another important capability of continuous simulation with respect to hydraulic performance is that it allows a more accurate assessment of the damage and risk potential of a stormwater management facility. By coupling a frequency analysis (that covers the full range of runoff responses rather than a snapshot of specific events) with a set of indicator variables that reflect the true damage potential, a reliable flood damage frequency assessment can be conducted.

Assessing the risk to public safety or the potential for property damage is best indicated by the flow depth and velocity, rather than flow rate or volume. It is the combination of depth and velocity of flow that actually causes damage, and such risks have been quantified by others, including:

human stability risk envelope (Abt et. al., 1989; Helsinki University of Technology, 2000); and

- damage risk envelope for brick or masonry buildings (Clausen and Clark, 1990).

A detailed damage and risk analysis was not completed for the Alton Mill study; however, Figure 10.8 illustrates the usefulness of such an approach. This figure plots the maximum computed depth and velocity in surface overflow channels represented in the continuous simulation model under proposed conditions.

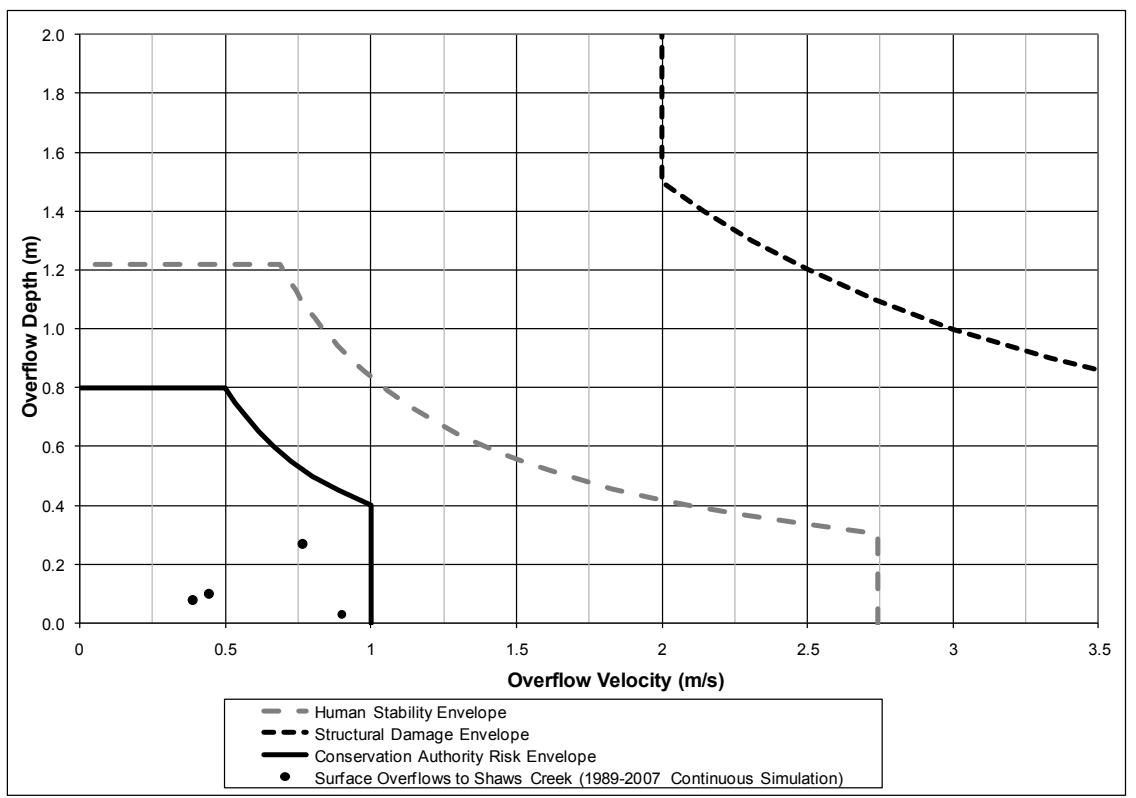

Figure 10.8 Surface overflow results. 
Figure 10.8 plots the overflow channel results against the human stability and damage risk envelopes for brick or masonry buildings that were referenced above. Further, an additional risk envelope was defined based on the local regulatory agency (Credit Valley Conservation Authority) safe access criteria for buildings. Their policy requires that flooding depths adjacent to buildings and structures do not exceed $0.8 \mathrm{~m}$. The risk envelope was extended using floodplain management criteria from the adjacent Grand River Conservation Authority. The complete risk envelope is defined by the following criteria and is plotted in Figure 10.8:

depth does not exceed $0.8 \mathrm{~m}$;

product of velocity and depth does not exceed $0.4 \mathrm{~m}^{2} / \mathrm{s}$; and velocity does not exceed $1 \mathrm{~m} / \mathrm{s}$.

In contrast to the poor hydraulic performance suggested by the analysis of peak stages and flow rates for the design storm events, Figure 10.8 provides some level of assurance that the stormwater management system will operate within an acceptable tolerance of flood risk.

\subsection{Conclusions}

The sizing of stormwater management facilities across North America largely relies on event-based hydrologic modeling methods, which continue to be prescribed in local stormwater design guidelines. These traditional methods originated in times when flood control and peak flow management was the sole design objective. With the increasing popularity in LID and green infrastructure initiatives, contemporary stormwater management is now concerned with water balance as an additional design objective that would maximize surface runoff volume reductions onsite. Event based methods cannot be used to sufficiently assess the long term volume control performance of such facilities.

This conclusion extends beyond small scale source controls and can be applied to stormwater management facilities in general. Continuous simulation offers a greater diagnostic tool for assessing hydraulic performance compared to event based modeling, since it can describe the full range of runoff response characteristics, versus a snapshot of selected individual return period events. As a consequence, in lieu of monitoring, only continuous simulation can be used to assess the long term average performance of a stormwater facility. Further, results describing the duration of runoff (e.g. flood inundation) or quantifying the various hydrologic components in a water balance calculation are more meaningful with continuous simulation. With event based simulation, the assessment of duration is only useful as a relative measure for comparing alternatives. 
Ultimately however, the key consideration in stormwater design is minimizing the risks to public safety and property damage. It is common practice to assess the hydraulic performance of stormwater facilities based on controlling peak flow rates, and in some cases runoff volume, to pre-development conditions. Neither one of these variables can accurately quantify the associated flood risk or property damage potential: the depth and velocity of flow are more appropriate indicators. A true assessment of risk can only be achieved by integrating these risk based indicators with the full range of flow frequencies computed using continuous simulation.

\section{Acknowledgments}

The authors would like to acknowledge the following people for their guidance and enthusiastic support during our involvement in the Alton Mill Initiative:

Jeremy Grant and Jordan Grant (Seaton Group);

Owen Scott (Landplan Collaborative Ltd.); and

Cathy Nasmith (Catherine Nasmith Architect).

\section{References}

Abt, S.R., R.J. Wittler, A. Taylor, and D.J. Love (1989). Human Stability in a High Flood Hazard Zone. American Water Resources Association, Water Resources Bulletin, 25:4, pp. 881-890.

Adams, B.J., and C.D.D. Howard (1986). Design Storm Pathology. Canadian Water Resources Association, Canadian Water Resources Journal, 11:3, pp. 49-55.

Clausen, L. and P.B. Clark (1990). The Development of Criteria for Predicting Dambreak Flood Damages using Modeling of Historical Dam Failures. In: International Conference on River Flood Hydraulics, pp. 369-380. John Wiley \& Sons Ltd.

Environment Canada (2008). Canadian Climate Normals or Averages 1971-2000. National Climate Data and Information Archive.

Gregory, M., M.F. Schmidt and J. Aldrich. 2003. "Level of Service Evaluations For Stormwater Assessments." Journal of Water Management Modeling R215-04. doi: 10.14796/JWMM.R215-04.

Reineman, M.C. (2004). NetSTORM - A Computer Program for Rainfall-Runoff Simulation and Precipitation Analysis. In "Critical Transitions In Water And Environmental Resources Management" by the American Society of Civil Engineers.

Helsinki University of Technology (2000). Final Report of The Use of Physical Models in Dambreak Flood Analysis, Part III - Human Stability in Flowing Water.

Town of Caledon (2006). Development Standards, Policies \& Guidelines document (Version 3). Public Works \& Engineering Department.

USEPA (U.S. Environmental Protection Agency) (2010). Storm Water Management Model User's Manual, Version 5.0. National Risk Management Research Laboratory, Office of Research and Development, EPA/600/R-05/040. Cincinnati, OH. 